\title{
Systematic analysis of xanthomonads (Xanthomonas spp.) associated with pepper and tomato lesions
}

\author{
J. B. Jones, ${ }^{1,2}$ H. Bouzar, ${ }^{1}+$ R. E. Stall, ${ }^{2}$ E. C. Almira, ${ }^{3}$ P. D. Roberts, ${ }^{1}$ \\ B. W. Bowen, ${ }^{4}$ J. Sudberry, ${ }^{1}$ P. M. Strickler ${ }^{1}$ and J. Chun ${ }^{1}$
}

Author for correspondence: J. B. Jones. Tel: +1 352392 7244. Fax: +1 3523926532.

e-mail: jbjones@nersp.nerdc.ufl.edu

1 Gulf Coast Research and Education Center, University of Florida, Bradenton, FL 34203, USA

2 Department of Plant Pathology, Fifield Hall, PO Box 110680, University of Florida, Gainesville, FL 32611-0680, USA

3 DNA Sequencing Core, PO Box 110699, University of Florida, Gainesville, FL 32611, USA

4 Department of Fisheries and Aquatic Sciences, University of Florida, Gainesville, FL 32653, USA

\begin{abstract}
The taxonomy and evolutionary relationships among members of the genus Xanthomonas associated with tomato and pepper have been a matter of considerable controversy since their original description in 1921. These bacteria, which are a major affliction of tomato and pepper crops in warm and humid regions, were originally described as a single species, but subsequent research has shown the existence of at least two genetic groups differentiated by physiological, biochemical and pathological characteristics. This work synthesizes the findings from several approaches, including pathogenicity tests, enzymic activity, restriction fragment analysis of the entire genome, DNA-DNA hybridization and RNA sequence comparisons based on a 2097 base sequence comprising the 165 rRNA gene, the intergenic spacer located between the 165 and 235 rRNA genes and a small region of the 235 rRNA gene. Within the group of xanthomonads pathogenic on pepper and tomato four distinct phenotypic groups exist, of which three form distinct genomic species. These include Xanthomonas axonopodis pv. vesicatoria (A and C group), Xanthomonas vesicatoria (B group) and Xanthomonas gardneri (D group). On the basis of phenotypic and genotypic differences between A- and C-group strains, the $C$ strains should be considered as a subspecies within Xanthomonas axonopodis pv. vesicatoria.
\end{abstract}

Keywords: fluorimetric DNA hybridization, pulsed field gel electrophoresis, bacterial taxonomy, APIZYM, phylogenetic analysis

\section{INTRODUCTION}

Bacterial spot disease on pepper and tomato is a major problem where high temperatures and high humidity occur simultaneously. Ethel M. Doidge (Doidge, 1921) originally identified the causal agent in South Africa as Bacterium vesicatorium. In the same year, Gardner and Kendrick (1921) identified a similar organism in the United States, naming it Bacterium exitiosum. When they became aware of Doidge's work, they deferred to her taxonomy and adopted B. vesicatorium as the

† Present address: Sakata Seed America, Inc., 105 Boronda Road, Salinas, CA 93907, USA.

The GenBank/EMBL/DDBJ accession numbers for the 2097 base fragment of strains XV1111 ${ }^{\top}, \mathrm{XV153}, \mathrm{XV338}, \mathrm{XV} 938$, Xanthomonas campestris pv. campestris (XCC') and 'Xanthomonas gardneri' (XCGA2) are, respectively: AF123088, AF123089, AF123090, AF123091, AF123092 and AF123093. name of the causal agent (Gardner \& Kendrick, 1921). However, they noted one difference between the two strains: the bacterium isolated by Doidge was feebly amylolytic, whereas their strains were strongly amylolytic. Two years later, Gardner \& Kendrick (1923) identified bacterial spot disease on pepper, determined that it was the same affliction observed on tomato and classified it as $B$. vesicatorium. In subsequent nomenclatural revisions, the bacterium was transferred to Xanthomonas (Dowson, 1939) as Xanthomonas vesicatoria and eventually to Xanthomonas campestris pv. vesicatoria (X. c. vesicatoria) by Dye (1978). Although considerable phenotypic diversity within the organism was observed in the 1960s (Dye et al., 1964) it was not until the 1990s that it was known that more than one species was responsible for the Xanthomonas diseases on pepper and tomato. Stall et al. (1994) and Vauterin et al. (1990) determined that two genetically distinct groups existed within $X$. c. vesicatoria. Stall et 
al. (1994) designated the two groups as A and B. Recently, Vauterin et al. (1995) reclassified the xanthomonads and divided those in $X$. c. vesicatoria into two species, X. vesicatoria and Xanthomonas axonopodis pv. vesicatoria ( $X$. a. vesicatoria). On the basis of the studies by Stall et al. (1994) and the reclassification scheme of the Xanthomonas genus presented by Vauterin et al. (1995), the group A strains are now members of $X$. a. pv. vesicatoria and the group B strains are members of $X$. vesicatoria.

Bouzar et al. (1994a) documented phenotypic diversity in a worldwide collection of strains which represented the two new species. The strains were variable in terms of carbon substrate utilization patterns, serovar and fatty acid profiles. One phenotypic trait that proved useful for differentiating the two species was starch hydrolysis (Bouzar et al., 1996); 252 strains were compared and it was demonstrated that the ability to significantly hydrolyse starch in less than $2 \mathrm{~d}$ was associated only with $X$. vesicatoria (B group) strains and not with $X$. a. vesicatoria (A group) strains. Later, analysis of strains from the Caribbean and Central America revealed that considerable phenotypic diversity existed in Central America (Bouzar et al., 1999, 1994b). Strains were identified which were not typical of A- or B-group strains. Furthermore, several amylolytic strains, which were isolated from samples collected in Mexico (Bouzar et al., 1996) and the Midwest of the United States, differed from typical B strains by reacting with a panel of monoclonal antibodies like A strains (Bouzar et al., 1994a, b, c, 1996): these are designated group A1 in this paper. Another group of amylolytic strains was discovered (Bouzar et al., 1996; Jones et al., 1995), but these strains differed from the B-group strains both serologically and pathogenically and were designated group C (Bouzar et al., 1996).

In 1957, a bacterial disease of tomato was identified (Šutic, 1957) and originally classified as 'Pseudomonas gardneri'. Later, Dye (1966) examined 'P. gardneri' and determined that it was a typical xanthomonad according to morphological and biochemical tests. Dye (1966) concluded that 'Xanthomonas gardneri' was a synonym of $X$. vesicatoria, since both bacteria produced a similar disease on tomato and could not be distinguished by physiological and pathological procedures. Placement of ' $P$. gardneri' in the genus Xanthomonas was further supported by DNA-rRNA hybridization studies (De Ley, 1978). However, in DNA-DNA hybridization tests ' $X$. gardneri' and $X$. $c$. pv. vesicatoria had very low reassociation values with each other, but $X$. gardneri showed reassociation of more than $60 \%$ with two other pathovars (Hildebrand et al., 1990; Palleroni et al., 1993). We presented preliminary information showing that several Xanthomonas species are pathogenic on tomato, including ' $X$. gardneri', $X$. vesicatoria (group B) and $X$. a. pv. vesicatoria (group A) (Bouzar et al., 1995).

In recent reports, DNA sequence comparisons have provided a new window into evolutionary relation- ships among prokaryotes (Olsen et al., 1994). In this paper we present phenotypic and genotypic information on the diversity of Xanthomonas strains associated with tomato and/or pepper, demonstrate that at least three distinct evolutionary lineages exist and clarify the relationships among ' $X$. gardneri,' $X$. vesicatoria and $X$. a. vesicatoria.

\section{METHODS}

Bacterial strains and storage. Seventeen Xanthomonas strains isolated from tomato and pepper and representing distinct phenotypic and genotypic groups were selected for characterization. The origin of the strains is described in Table 1 and their phenotypic traits are documented in Table 2. Other strains used in this study included the type strains of Xanthomonas albilineans, $X$. axonopodis, X. campestris, Xanthomonas fragariae and Xanthomonas oryzae. The strains were stored in $15 \%$ glycerol at $-70{ }^{\circ} \mathrm{C}$ for long-term preservation.

mAb production and serological typing of strains. A representative group $\mathrm{C}$ strain, XV938, was used as the immunogen to produce a $\mathrm{mAb}$. The $\mathrm{mAb}$ was produced as previously described by Bouzar et al. (1994a). ELISA reactions were converted to positive and negative reactions with a cut-off for positive reactions at $A_{405} \geqslant 0 \cdot 1$.

Pathogenicity tests. Single colonies were transferred to nutrient broth and shaken overnight at $30{ }^{\circ} \mathrm{C}$ and the bacterial suspensions were centrifuged. The resulting pellets were resuspended in sterile tap water and the suspensions of cells were standardized to an optical density at $600 \mathrm{~nm}$ of $0 \cdot 3$ (approx. $5 \times 10^{8}$ c.f.u. $\mathrm{ml}^{-1}$ ). Seedlings of pepper (cultivar Early Calwonder) and tomato (cultivar Bonny Best) were grown in a greenhouse in $15-\mathrm{cm}$ pots containing a steamed peat/vermiculite mixture; a soluble $20: 20: 20$ fertilizer $(0.4 \mathrm{~g}$ per pot; Peters Fertilizer Products, W. R. Grace) was added to the plants biweekly. To observe the disease symptoms produced by the different strains, leaves of both tomato and pepper plants were inoculated by swabbing inoculum onto leaves that were not fully expanded, by using a cotton applicator saturated with a bacterial suspension amended with carborundum. After inoculation, symptom development was observed periodically for 3 weeks.

Enzymic activity. We used the API gallery, type API ZYM (API BioMérieux) to compare 19 enzymic reactions of the strains listed in Table 1. Bacterial growth was suspended in sterile saline and adjusted to $1.5-1.8 \times 10^{9}$ c.f.u. $\mathrm{ml}^{-1}$. Enzymic activity was determined according to the manufacturer's recommendations. The tests were scored on a scale from 0 to 5. Comparative data for each strain-enzymic reaction was tabulated and the similarity coefficient between two strains was calculated with the SIMINT program from NTSYS-pc version 1.80 (Exeter Software). Cluster analysis by the unweighted pair-group method was performed using the SAHN program from NTSYS-pc. Data for amylolytic and pectolytic activities were obtained from a previous study (Bouzar et al., 1994a).

Restriction endonuclease analysis. Genomic DNAs of the bacterial strains (Table 1) were prepared and digested with restriction endonucleases $X b a \mathrm{I}, V s p \mathrm{I}$ and $S p e \mathrm{I}$ as described by Egel et al. (1991). The resulting large DNA fragments were separated by PFGE. The gels were stained with ethidium bromide and photographed with type 55 Polaroid 
Table 1. Xanthomonas strains

See Table 2 for characteristics of groups A, A1, B, C and D.

\begin{tabular}{|c|c|c|c|}
\hline Current nomenclature & Strain & $\begin{array}{c}\text { Original } \\
\text { designation }\end{array}$ & Source* \\
\hline$X$. albilineans & $\mathrm{XAL}^{\mathrm{T}}$ & ATCC $12785^{\mathrm{T}}$ & ATCC \\
\hline X. axonopodis pv. axonopodis & $\mathrm{XAX}^{\mathrm{T}}$ & ATCC $19312^{\mathrm{T}}$ & ATCC \\
\hline$X$. axonopodis pv. vesicatoria & XV153 & $75-3$ & Stall \\
\hline$X$. axonopodis pv. vesicatoria & XV155 & $85-16$ & Stall \\
\hline$X$. axonopodis pv. vesicatoria & XV157 & $89-10$ & Hibberd \\
\hline$X$. axonopodis pv. vesicatoria & XV330 & Barbados 1 & Jones \\
\hline$X$. axonopodis pv. vesicatoria & XV338 & Barbados 2 & Jones \\
\hline$X$. axonopodis pv. vesicatoria & XV1085 & Mexico 1 & Jones \\
\hline$X$. axonopodis pv. vesicatoria & XV1605 & Ohio & Miller \\
\hline$X$. axonopodis pv. vesicatoria & XV938 & Florida & Jones \\
\hline$X$. axonopodis pv. vesicatoria & XV1220 & Thailand & Jones \\
\hline$X$. axonopodis pv. vesicatoria & XV1484 & Mexico 2 & Jones \\
\hline$X$. campestris pv. campestris & $\mathrm{XCC}^{\mathrm{T}}$ & ATCC $33913^{\mathrm{T}}$ & ATCC \\
\hline$X$. campestris & XV1194 & XCV857 & Louws \\
\hline$X$. fragariae & $\mathrm{XF}^{\mathrm{T}}$ & ATCC $33239^{\mathrm{T}}$ & ATCC \\
\hline 'X. gardneri' & XCGA2 & XG101 & Hildebrand \\
\hline 'X. gardneri' & XV444 & Costa Rica 1 & Jones \\
\hline 'X. gardneri' & XV451 & Costa Rica 2 & Jones \\
\hline 'X. graminis' & $X G$ & ATCC 29091 & ATCC \\
\hline$X$. oryzae & $\mathrm{XOA}^{\mathrm{T}}$ & ATCC $35933^{\mathrm{T}}$ & ATCC \\
\hline$X$. vesicatoria & $\mathrm{XV} 1111^{\mathrm{T}}$ & ATCC $35937^{\mathrm{T}}$ & ATCC \\
\hline$X$. vesicatoria & XV56 & X 525-85 & Nagai \\
\hline$X$. vesicatoria & XV141 & $71-4$ & Starr \\
\hline$X$. vesicatoria & XV144 & BV20-3A & Alippi \\
\hline
\end{tabular}

* Details of sources: ATCC, American Type Culture Collection; A. Alippi, Universidad Nacional de la Plata, La Plata, Buenos Aires, Argentina; A. Hibberd, Redlands Research Centre, Cleveland, Queensland, Australia; J. B. Jones, University of Florida, Gulf Coast Research and Education Center, Bradenton, FL, USA; F. Louws, Michigan State University, Plant Research Laboratory, Department of Energy, Plant Biology Building, East Lansing, MI, USA; H. Nagai, Instituto Agronomico, Sao Paulo, Brazil; S. A. Miller, Ohio State University, Plant Pathology Department, Wooster, OH 44691, USA; R. E. Stall, University of Florida, Department of Plant Pathology, Gainesville, FL, USA; M. P. Starr, University of California at Davis, Davis, CA, USA.

Table 2. Phenotypic groups of phytopathogenic xanthomonads associated with tomato and pepper

\begin{tabular}{|c|c|c|c|c|c|c|c|}
\hline $\begin{array}{l}\text { Phenotypic } \\
\text { group }\end{array}$ & Strain & Distribution & $\mathbf{m A b} \mathbf{b}^{*}$ & $\begin{array}{c}\text { Protein } \\
\text { (kDa) }\end{array}$ & PFGE $\dagger$ & $\begin{array}{c}\text { Amylolytic } \\
\text { activity }\end{array}$ & $\begin{array}{c}\text { Pectate } \\
\text { hydrolysis }\end{array}$ \\
\hline A & XV153, XV155, XV157 & Worldwide & 1,21 & 32 & A & - & - \\
\hline A1 & $\begin{array}{l}\text { XV1085, XV1605, XV330, } \\
\text { XV338 }\end{array}$ & Barbados, Mexico, Ohio & 1,21 & 25 & A & + & + \\
\hline B & $\begin{array}{l}\text { XV56, XV144, XV141, } \\
\text { XV1111 }\end{array}$ & Worldwide & 8,15 & 27 & B & + & + \\
\hline $\mathrm{C}$ & XV938, XV1220, XV1484 & Mexico, Thailand, USA & 30 & 27 & $\mathrm{C}$ & + & + \\
\hline $\mathrm{D}$ & XCGA2, XV444, XV451 & Costa Rica, Yugoslavia & 8 & 27 & $\mathrm{D}$ & - & - \\
\hline
\end{tabular}

* mAb developed using Xanthomonas campestris pv. vesicatoria strains that react in ELISA (Bouzar et al., 1994b).

$\dagger$ PFGE group (see Fig. 2). Group A includes A and A1 strains from Fig. 2.

$\ddagger+$, Starch hydrolysis visible in less than $2 \mathrm{~d}$. 
film. All strains were run on the same gel and similarity coefficients were determined for strains by comparing fragments greater than $100 \mathrm{~kb}$ (Egel et al., 1991). Similarity values were calculated as described by Egel et al. (1991) by using the mathematical equation proposed by $\mathrm{Nei}$ and $\mathrm{Li}$ (1987) based on the proportion of shared DNA fragments. The number of nucleotide substitutions per site was estimated by the iterative method of Nei (1987) by using the SAS program as described by Leite et al. (1994). The KITSCH program from the PHYLIP computer package (Felsenstein, 1995) was used to infer a rooted phylogenetic tree by using the Fitch-Margoliash method (Fitch \& Margoliash, 1967). The input data consisted of a matrix of pairwise genetic distances determined as estimates of the numbers of nucleotide substitutions per site on the basis of similarity coefficients calculated for the combined digestion data of the three enzymes (Leite et al., 1994).

Sequence determination and phylogenetic analysis. Isolation of total genomic DNA, PCR and electrophoresis conditions were as described elsewhere (Ausubel et al., 1987). Amplification of rrs (the 16S rRNA gene) and the intergenic spacer (IGS) located between $r r s$ and $r r l$ (i.e. the 23S rRNA gene) was performed with standard PCR conditions (Innes et al., 1995) using primers FGPS6-63 (5'-GGA GAG TTA GAT CTT GGC TCA G-3') and FGPL132'-38 (5'-CCG GGT TTC CCC ATT CGG-3') as previously described (Ponsonnet \& Nesme, 1994).

Six additional oligo primers were synthesized at the DNA Synthesis Core Laboratory (University of Florida, Gainesville, FL, USA) for sequencing of the PCR product. These primers were HAB1 (5'-CCG CAC CTT CCG ATA CG-3'), HAB2 (5'-GTG CGT AGG TGG TGG TTT-3'), HAB3 (5'CCC AGG CGG CGA ACT T-3'), HAB4 (5'-AAC CGA CTG CTT TTC TTT-3'), HAB5 (5'-AAG CCA ATC CCA GAA ACC-3') and HAB6 (5'-ATC CCG ACA GGC TCC AC-3').

PCR products were purified with Ultrafree MC 30000 MW filters (Millipore). Double-stranded sequencing reactions were conducted at the University of Florida DNA Sequencing Core Laboratory using ABI Prism Dye Terminator cycle sequencing protocols (part number 402078) developed by Applied Biosystems (Perkin-Elmer). Oligo primers (i.e. HAB1-HAB6) were designed using OLIGO 5.0 (National BioSciences) and synthesized at the University of Florida DNA Synthesis Core Laboratory. The fluorescently labelled extension products were analysed with an automated DNA sequencer (model 377; Applied Biosystems). Raw data from the sequencer were edited and aligned using SEQUENCHER version 3.0 (Gene Codes) and the default options in the program CLUSTAL W (Thompson et al., 1994). All samples were sequenced in the forward and reverse directions to ensure the accuracy of nucleotide sequence designations.

Sequence divergences between haplotypes, including the gaps, were estimated with the Kimura two-parameter model (Kimura, 1980) with a 3:1 transition:transversion ratio, using the algorithm in PHYLIP version 3.57 (Felsenstein, 1993). To elucidate relationships among haplotypes, evolutionary trees were generated with the neighbour-joining method (Saitou \& Nei, 1987) in MEGA (version 1.02; Kumar et al., 1994) and the parsimony approach of PAUP version 3.1.1 (Swofford, 1993). Support for nodes in both the neighbour-joining and the parsimony approaches was assessed with a bootstrap confidence level using 500 replicates.

DNA-DNA hybridization. DNA-DNA relatedness analysis was performed in a microplate and determined using the fluorimetric assay of Ezaki et al. (1989) with minor modifications. Large molecular mass DNA was extracted from strains of $X$. vesicatoria and $X$. axonopodis pv. vesicatoria representative of the RFLP groups identified in this study and the type strains of $X$. c. campestris, $X$. albilineans, $X$. fragariae, $X$. oryzae, $X$. axonopodis pv. axonopodis (X. a. axonopodis) and 'Xanthomonas graminis'. DNA extraction and purification were performed according to Marmur's procedure, as described by Johnson (1994). The DNA was fragmented by three passages through a French pressure cell under $110316 \mathrm{kPa}$, resulting in DNA fragments approx. $0.5 \mathrm{~kb}$ in size. The DNA was heat-denatured and used either for coating microdilution plates (MicroFluor type B; Dynatech) or biotinylated for use as a probe. Each microtitre well was coated with $3 \mu \mathrm{g}$ fragmented, denatured DNA. The probe contained 20-50 ng DNA labelled with Photoprobe biotin (Vector) according to the manufacturer's protocol. Hybridization was carried out at $52{ }^{\circ} \mathrm{C}$ for $12 \mathrm{~h}$. DNA reassociation ratios were determined fluorimetrically (7630 Microplate Fluorometer; Cambridge Technology) $1 \mathrm{~h}$ after the binding of $\beta$-galactosidase avidin D (Vector Laboratories) and the addition of the 4-methylumbelliferyl- $\beta$-Dgalactoside substrate (Sigma). Hybridization experiments were repeated three times and consisted of three replications of each probe with every strain.

\section{RESULTS}

\section{mAb reactions}

$\mathrm{mAb} 30$ was produced and tested against several hundred strains representing A- and B-group strains, representative strains of other Xanthomonas species, more than 100 group $C$ strains and all strains used in this study. It reacted with all group $\mathrm{C}$ strains, but not with any of the other strains including those shown in Table 2 .

\section{Pathogenicity tests}

All strains (with the exception of XV1194) used in this study that were isolated from pepper or tomato were pathogenic on pepper, tomato or both (Table 3).

Table 3. Pathogenic reaction of selected strains isolated from tomato and pepper on 'Early Calwonder' pepper and 'Bonny Best' tomato

+ , Disease; - , hypersensitive reaction.

\begin{tabular}{|lcc|}
\hline Strain & Pepper & Tomato \\
\hline XCC $^{\mathrm{T}}, \mathrm{XV1194}$ & - & - \\
XV153, XV155, XV157, XV1085, & + & + \\
XV1605, XV330, XV338, XV444, & & \\
XV451 & & \\
XV938, XV1220, XV1484, XV1111 & \\
XV56, XV141, XV144, XCGA2 & - & + \\
\hline
\end{tabular}




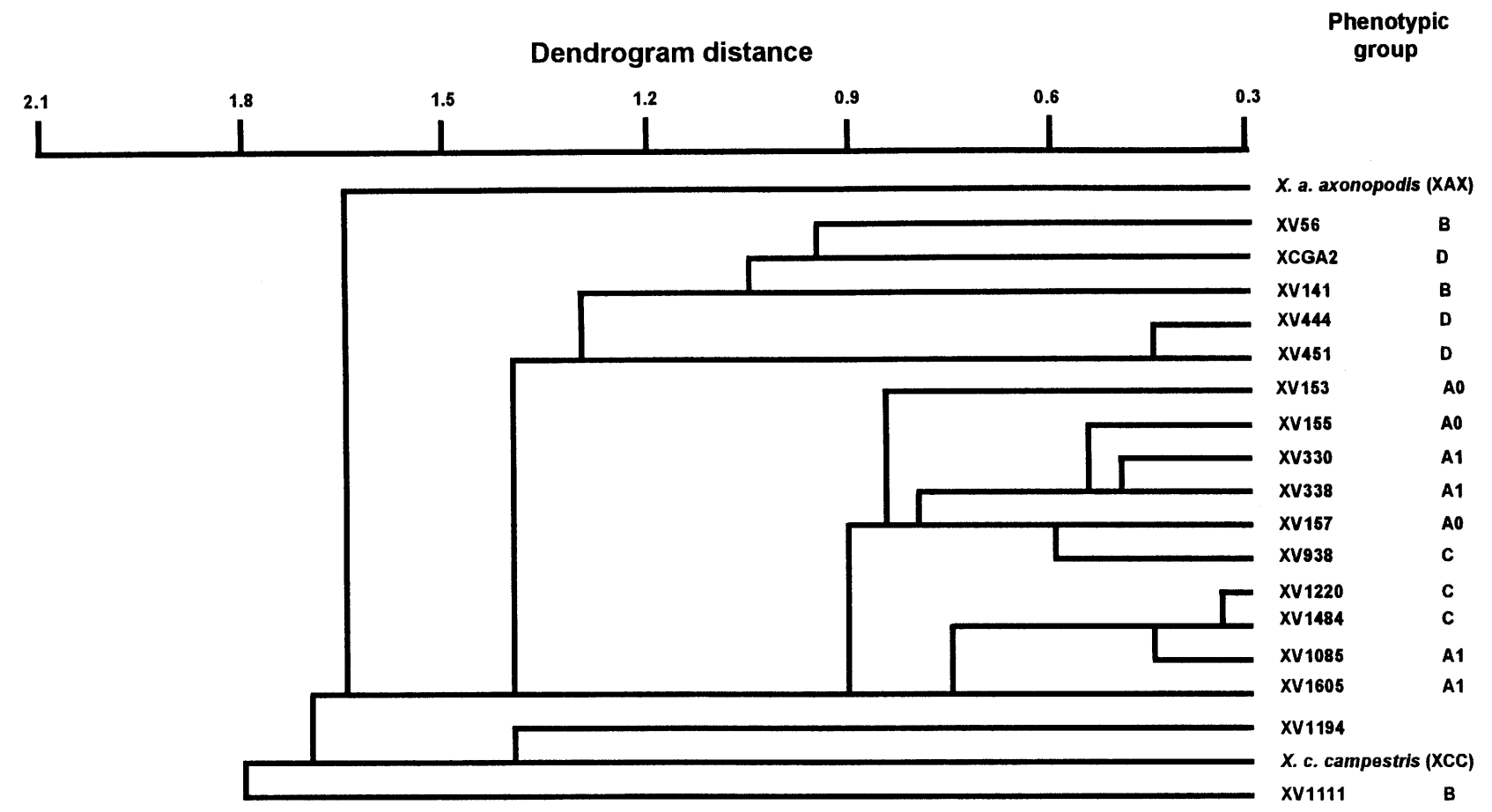

Fig. 1. Clustering of group $A, B, C$ and $D$ strains based on enzymic activity using the API ZYM gallery.

Although XV1194 was isolated from tomato, symptoms typical of a disease reaction were not observed on either pepper or tomato. However, a reaction characteristic of hypersensitivity was observed on those plants $5 \mathrm{~d}$ after inoculation. On cabbage seedlings, XV1194 induced leaf spots and stem lesions similar to those induced by Xanthomonas campestris pv. armoraciae and Xanthomonas campestris pv. raphani; infection did not result in typical black-rot symptoms typical of $X$. c. campestris.

\section{Enzymic activity analysis}

A dendrogram was constructed using the clustering method of NTSYS. Two major clusters were evident (Fig. 1). One large cluster consisted of strains from groups A, A1 and C. A second but more divergent cluster consisted of two B strains (XV56 and XV141), the ' $X$. gardneri' strain (XCGA2) originally from Yugoslavia and two D strains (XV444, XV451) from Costa Rica. Considerable variability existed between strains within the B group, the $X$. vesicatoria type strain $\left(\mathrm{XV} 1111^{\mathrm{T}}\right)$ being very remote from the two other B strains (XV56 and XV141). X. a. axonopodis $\left(\mathrm{XAX}^{\mathrm{T}}\right), X$. c. campestris $\left(\mathrm{XCC}^{\mathrm{T}}\right)$ and $\mathrm{XV} 1194$ were distantly related to xanthomonads pathogenic on tomato and/or pepper.

\section{Restriction endonuclease analysis}

In the dendrogram generated from the similarity coefficient obtained by averaging the similarity coefficients for $S p e \mathrm{I}, X b a \mathrm{I}$ and $V s p \mathrm{I}$, five clusters were

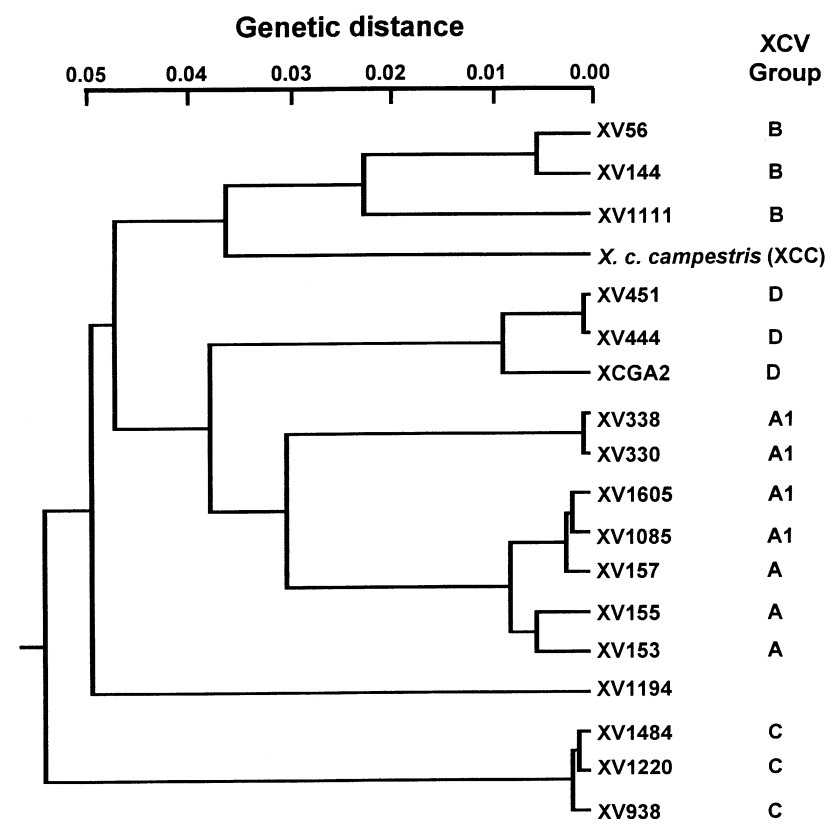

Fig. 2. Clustering of group $A, B, C$ and $D$ strains inferred from similarity coefficients obtained from Spel, Xbal and Vspl restriction endonuclease data. The tree was generated by the $\mathrm{KITSCH}$ procedure with the PHYLIP computer package by using the Fitch-Margoliash method. The genetic distances are estimates of the numbers of nucleotide substitutions per site.

distinguished (Fig. 2). Greater genetic divergence was observed for strains in the A group than for strains in any of the other groups. The A strains formed two 


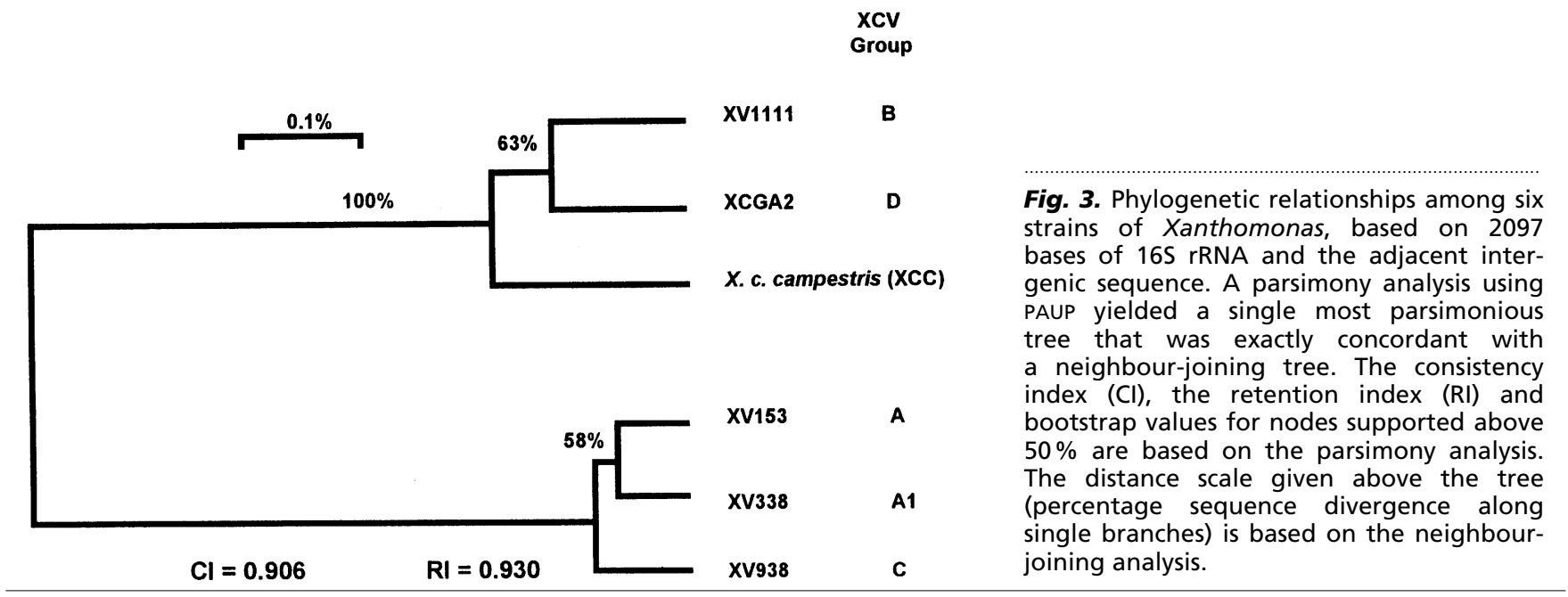

clusters. One cluster contained typical A strains (XV153, XV155 and XV157) and two of the amylolytic A1 strains (XV1085 and XV1605), whereas the other cluster consisted of two amylolytic A1 strains (XV330 and XV338) from Barbados. The B strains formed a separate, less divergent cluster than the A group. The three C-group strains formed a very tight cluster sharing a high percentage of similarity and were most distantly related to the other groups. Strains representative of the D group (XV444 and XV451) clustered with the ' $X$. gardneri' (XCGA2) strain. Strain XV1194 and, to a lesser extent, the type strain of $X$. c. campestris did not cluster with any group.

\section{RNA sequence comparisons}

A fragment of 2097 bases was resolved in all six strains. The sequence data have been submitted to GenBank. Overall diversity was low, with 39 variable sites containing 22 transitions, 7 transversions and 11 single-base indels. Site 1985 contained both an indel and a transversion.

Genetic distances between lineages ranged from $d=$ 0.0014 (between group A strain XV153 and group A1 strain XV338) to $d=0.0118$ (between strain XV153 and group B strain $\mathrm{XV} 1111^{\mathrm{T}}$ ). All tree-building methods resolved two clusters of haplotypes: strains $\mathrm{XV} 1111^{\mathrm{T}}$ (group B), 'X. gardneri' (group D) and X.c. campestris $\left(\mathrm{XCC}^{\mathrm{T}}\right)$ were distinguished from the group A strains XV153 and XV338 and from the group C strain XV938 with a mean divergence of $d=0 \cdot 0105$. Seventeen steps in the parsimony analysis distinguished these two clusters. The highest divergence within either cluster was $d=0.0033$, or nine steps in the parsimony analysis.

One most parsimonious tree generated by the PAUP method shows $100 \%$ support for a split into two monophyletic groups: $\mathrm{XV} 1111^{\mathrm{T}}$, ' $X$. gardneri' (XCGA2) and X.c. campestris $\left(\mathrm{XCC}^{\mathrm{T}}\right)$ forming one of the groups and XV153, XV338 and XV938 forming the other (Fig. 3). A dendrogram generated by the neighbour-joining method shows the same basic topology, including the two primary lineages observed in the parsimony analysis. Bootstrap support for the primary split in this phylogeny was $100 \%$. Support for the branching order within either cluster was 52-64\% in the neighbour-joining analysis and $59-65 \%$ in the parsimony analysis. This low level of support is presumably due to the shallow divergence between strains XV153 and XV338 (three site substitutions) and between strains XV1111 $1^{\mathrm{T}}$ and ' $X$. gardneri' (five site substitutions).

\section{DNA-DNA hybridization}

When the representative A strain, XV153, was used as the probe, the levels of hybridization with group A strains and the group C strain was higher than $80 \%$, whereas the value was lower than $50 \%$ against groups $\mathrm{B}$ and $\mathrm{D}$ (including ' $X$. gardneri') strains, $X$. $a$. axonopodis $\left(\mathrm{XAX}^{\mathrm{T}}\right)$ and the other Xanthomonas spp. (Table 4). When the two amylolytic A1 strains (XV330 and XV1085) were used as probes, relationships were observed which were similar to those that occurred with XV153. When the representative group C strain, XV938, was used as the probe, the level of hybridization was greater than $60 \%$ with the A1 strains (XV1085 and XV1605), between 50 and $60 \%$ with the A strains (XV153 and XV155) and less than $50 \%$ with all other strains tested. When the type strain of $X$. vesicatoria $\left(\mathrm{XV} 1111^{\mathrm{T}}\right)$ was used as the probe, the level of hybridization with XV56, another B-group strain, was greater than $80 \%$, whereas the level of hybridization with strains from other groups was less than $50 \%$. The levels of hybridization between XV444, a group D strain and ' $X$. gardneri' (XCGA2) was greater than $90 \%$ when each strain was used as a probe, whereas with DNA from other strains hybridization was less than $40 \%$. When XV1194 was used as a probe, it hybridized weakly with all strains except the type strain of X.c. campestris. The same was true for $X$. c. campestris when it was used as a probe. 
Table 4. Comparison of percentage DNA reassociation values for 17 Xanthomonas strains

Values are means of six readings and are normalized to the hybridization value of each probe.

\begin{tabular}{|c|c|c|c|c|c|c|c|c|c|c|c|c|c|c|c|c|c|c|}
\hline Probe & $\begin{array}{l}\text { Phernotypic } \\
\text { group }\end{array}$ & 1 & 2 & 3 & 4 & 5 & 6 & 7 & 8 & 9 & 10 & 11 & 12 & 13 & XAL & XOA & XG & $\mathbf{X F}$ \\
\hline 1. XV153 & A & 100 & 101 & 100 & 90 & 91 & 82 & 28 & 35 & 37 & 37 & 32 & 40 & 47 & 15 & 37 & 20 & 42 \\
\hline 2. XV155 & A & 95 & 100 & 90 & 90 & 82 & 72 & 30 & 28 & 33 & 35 & 32 & 36 & - & - & - & - & - \\
\hline 3. XV1085 & Al & 77 & 81 & 100 & 100 & 84 & 81 & 30 & 30 & 41 & 40 & 38 & 37 & 35 & 14 & 34 & 21 & 40 \\
\hline 4. XV1605 & Al & 83 & 80 & 96 & 100 & 86 & 68 & 31 & 33 & 38 & 37 & 33 & 45 & - & - & - & - & - \\
\hline 5. XV338 & Al & 74 & 75 & 84 & 89 & 100 & 78 & 28 & 32 & 35 & 34 & 30 & 36 & 43 & 14 & 34 & 20 & 37 \\
\hline 6. XV938 & $\mathrm{C}$ & 53 & 55 & 77 & 71 & 65 & 100 & 32 & 31 & 37 & 34 & 34 & 36 & 39 & 14 & 34 & 19 & 44 \\
\hline 7. XV56 & B & 30 & 31 & 36 & 37 & 37 & 35 & 100 & 86 & 44 & 35 & 36 & 45 & - & - & - & - & - \\
\hline 8. $\mathrm{XV} 1111^{\mathrm{T}}$ & B & 29 & 31 & 38 & 36 & 35 & 40 & 83 & 100 & 44 & 40 & 37 & 44 & 26 & 12 & 21 & 16 & 28 \\
\hline 9. XV444 & $\mathrm{D}$ & 26 & 27 & 30 & 33 & 29 & 32 & 31 & 32 & 100 & 91 & 34 & 40 & - & - & - & - & - \\
\hline 10. XCGA2 & $\mathrm{D}$ & 31 & 26 & 37 & 31 & 33 & 34 & 28 & 29 & 98 & 100 & 34 & 42 & 33 & 12 & 32 & 20 & 37 \\
\hline 11. XV1194 & - & 31 & 31 & 37 & 37 & 35 & 39 & 32 & 41 & 42 & 41 & 100 & 93 & - & - & - & - & - \\
\hline 12. $\mathrm{XCC}^{\mathrm{T}}$ & - & 26 & 29 & 35 & 30 & 31 & 30 & 30 & 35 & 32 & 38 & 73 & 100 & 24 & 16 & 28 & 20 & 35 \\
\hline 13. $\mathrm{XAX}^{\mathrm{T}}$ & - & 50 & - & 54 & - & 52 & 56 & - & 32 & - & 38 & - & 31 & 100 & 13 & 43 & 18 & 40 \\
\hline
\end{tabular}

\section{DISCUSSION}

The phenotypically distinct Xanthomonas strains associated with bacterial spot of tomato and pepper collected from diverse locations (Bouzar et al., 1994a, b; Stall et al., 1994) were determined to be distinct genotypically. Although two previous studies (Stall et al., 1994; Vauterin et al., 1995) showed that strains within the previously accepted specific epithet of $X . c$. pv. vesicatoria were actually two distinct species, we present further evidence to show that more than two distinct species cause disease on tomato and pepper.

Previously, strains associated with the species $X . c$. vesicatoria were shown (Stall et al., 1994; Vauterin et al., 1995) to form two genetic groups (i.e. A and B). The two groups were readily differentiated from each other in that B strains strongly hydrolysed starch and, to a lesser extent, degraded pectate, whereas A strains hydrolysed starch only after $14 \mathrm{~d}$ and were unable to degrade pectate (Bouzar et al., 1996; Stall et al., 1994). However, amylolytic and pectolytic strains typical of the B group were recently collected in the United States, Barbados and Mexico. Many of these strains were shown to be related to strains in the A group, on the basis of reaction profiles with mAbs, whereas others were different from both group A and B (Bouzar et al., 1999). On the basis of the unique phenotypic characteristics of these strains they were placed in two new phenotypic groups. The first phenotypic group, group A1, had PFGE patterns and serological reactions similar to those of A-group strains. DNADNA hybridization data confirmed the close relationship between A1 and A strains. Strains from the second group of amylolytic strains were phenotypically and genotypically distinct from A and B strains and were designated as group $\mathrm{C}$. This group of strains can easily be distinguished from A and A1 strains on the basis of PFGE profiles and reactions to antibodies and bacteriophages (J. B. Jones, H. Bouzar \& P. D. Roberts, unpublished results). However, on the basis of phylogenetic data, group $\mathrm{C}$ strains are closely related to those of groups A and A1. DNA-DNA hybridization data indicate that group $\mathrm{C}$ strains are distinct from group A strains, but that the two groups are close enough to be included in the same species as group A strains. Clearly, there are significant phenotypic and genotypic differences between A- and Cgroup strains, and the $\mathrm{C}$ strains should be considered as subspecies within $X$. a. vesicatoria.

The phylogenetic tree obtained from the sequence analysis of the $16 \mathrm{~S}$ rRNA gene and the IGS located between $r r s$ and $r r l$ clearly produced two clades on the tree. One branch included the representative B-group strain, 'X. gardneri' and X. c. campestris, whereas the other included the representatives of groups A, A1 and C. The DNA-DNA hybridization data corroborate the 16S rRNA sequencing data. The $\mathrm{C}$ strains, although phenotypically distinct from the A and B groups, were more closely related to the A strains. When Hauben et al. (1997) looked at sequence analysis of the 16S rRNA, only slight differences were detected between many xanthomonads. However, much of the variation needed to show differences between closely related species appears to be associated with the IGS, as shown by Leblond-Bourget et al. (1996). Furthermore, although close identity based on sequence analysis of $16 \mathrm{~S}$ rRNA may indicate that two organisms may be members of the same species, it is not necessarily the case, as demonstrated with Bacillus spp. in which 16S rRNA sequences were extremely close but DNA-DNA homologies were low (Fox et al., 1992). The converse has not been shown, i.e. where members of a species have high DNA-DNA homologies but low rRNA sequence similarity. Coupled with the fairly high relatedness between $\mathrm{A}$ and $\mathrm{C}$ strains based on DNA-DNA hybridization, the 16S rRNA sequence data appear to support the close genetic relationship between these two groups (Bouzar et al., 1995).

Šutic (1957) identified a tomato disease in Yugoslavia caused by ' $P$. gardneri' in 1957. This organism was considered to be a synonym of ' $X$. vesicatoria' (Dye, 1966) and this status was maintained for years. However, Hildebrand et al. (1990) and Palleroni et al. (1993), using DNA-DNA hybridization tests, deter- 
mined that ' $X$. gardneri' was not closely related to the B group ( $X$. vesicatoria), but was more closely related to several other pathovars of $X$. campestris. Comparisons were not made in either study with typical Agroup ( $X . a$. vesicatoria) strains. We demonstrated in this study that ' $X$. gardneri' is not closely related to either group A or group B but is instead a member of a third species that is pathogenic on tomato and/or pepper. Furthermore, ' $X$. gardneri' appears to occur rarely in nature, the type strain being the only known strain in existence. Analysis of an extensive collection of strains (Bouzar et al., 1994a) did not reveal any ' $X$. gardneri' strains; however, in a survey of Xanthomonas strains collected in the Caribbean and Central America, an organism very similar to ' $X$. gardneri' was found in Costa Rica (Bouzar et al., 1999, 1994b). On the basis of PFGE analysis, two of these strains (i.e. XV444 and XV451) collected in Costa Rica appeared to be closely related phylogenetically to ' $X$. gardneri'. Furthermore, DNA-DNA hybridization confirmed that these strains from Costa Rica and ' $X$. gardneri' belong to the same species.

From our analyses, it is evident that ' $X$. gardneri' strains are pathogens of tomato and/or pepper and that they are phenotypically and genetically distinct from both Xanthomonas exitiosa $(X$. vesicatoria sensu Vauterin et al.) and $X$. vesicatoria (X. a. vesicatoria sensu Vauterin et al.). Furthermore, they represent a species that is distinct from the latter two. Further comparisons with the type strains of the other Xanthomonas species will be needed in order to place them in the correct species.

\section{ACKNOWLEDGEMENTS}

Florida Agricultural Experiment Station Journal Series no. R-06518.

\section{REFERENCES}

Ausubel, F. M., Brent, R., Kingston, R. E., Moore, D. D. \& Seidman, K. (1987). Current Protocols In Molecular Biology. New York: Wiley.

Bouzar, H., Jones, J. B., Stall, R. E., Hodge, N. C., Minsavage, G. V., Benedict, A. A. \& Alvarez, A. M. (1994a). Physiological, chemical, serological, and pathogenic analyses of a worldwide collection of Xanthomonas campestris pv. vesicatoria strains. Phytopathology 84, 663-671.

Bouzar, H., Jones, J. B., Stall, R. E., Somodi, G. C., Kelly, R. O. \& Daouzli, N. (1994b). Phenotypic characterization of Xanthomonas campestris pv. vesicatoria strains from the Caribbean and Central America. Phytopathology 84, 1069.

Bouzar, H., Jones, J. B., Minsavage, G. V., Stall, R. E. \& Scott, J. W. (1994c). Proteins unique to phenotypically distinct groups of Xanthomonas campestris pv. vesicatoria revealed by silver staining. Phytopathology 84, 39-44.

Bouzar, H., Jones, J. B., Stall, R. E. \& Sudberry, J. J. (1995). Homology groups of Xanthomonas campestris pv. vesicatoria (Xcv) based on DNA hybridization in microtiter plates. Phytopathology 85, 1148.

Bouzar, H., Jones, J. B., Somodi, G. C., Stall, R. E., Daouzli, N., Lambe, R. C., Felix-Gastelum, R. \& Trinidad-Correa, R. (1996).
Xanthomonas campestris pv. vesicatoria race variation in tomato and pepper fields of Mexico. Can J Plant Pathol 18, 75-77.

Bouzar, H., Jones, J. B., Stall, R. E., Louws, F., Schneider, F. J., Rademaker, M., de Bruijn, J. W. L. \& Jackson, L. E. (1999). Multiphasic analysis of xanthomonads causing bacterial spot disease on tomato and pepper in the Caribbean and Central America: evidence for common lineages within and between countries. Phytopathology 89, 328-335.

De Ley, J. (1978). Modern molecular methods in bacterial taxonomy: evaluation, application, prospects. In Proceedings of the 4th International Conference on Plant Pathogenic Bacteria, Angers, pp. 347-357.

Doidge, E. M. (1921). A tomato canker. Ann Appl Biol 7, 407-430.

Dowson, W. J. (1939). On the systematic position and generic names of the gram negative bacterial plant pahtogens. Zentbl Bakteriol Parasitenk Infektionskr Hyg Abt II 100, 177-193.

Dye, D. W. (1966). Cultural and biochemical reaction of additional Xanthomonas species. N Z J Sci 9, 913-919.

Dye, D. W. (1978). Genus IX. Xanthomonas. Dowson (1939). In A Proposed Nomenclature and Classification for Plant Pathogenic Bacteria. Edited by J. M. Young, D. W. Dye, J. F. Bradbury, C. G. Panagopoulos \& C. F. Robbs. N Z J Agric Res 21, 153-177.

Dye, D. W., Starr, M. P. \& Stolp, H. (1964). Taxonomic clarification of Xanthomonas vesicatoria based upon host specificity, bacteriophage sensitivity, and cultural characteristics. Phytopathol Z 51, 394-407.

Egel, D. S., Graham, J. \& Stall, R. E. (1991). Genomic relatedness of Xanthomonas campestris strains causing diseases of citrus. Appl Environ Microbiol 57, 2724-2730.

Ezaki, T., Hashimoto, Y. \& Yabuuchi, E. (1989). Fluorometric deoxyribonucleic acid-deoxyribonucleic acid hybridization in microdilution wells as an alternative to membrane filter hybridization in which radioisotopes are used to determine genetic relatedness among bacterial strains. Int $J$ Syst Bacteriol 39, 224-229.

Felsenstein, J., (1993). PHYLIP (Phylogeny Inference Package) version 3.57. Computer program and manual distributed by the author.

Felsenstein, J. (1995). PHYLIP. (Phylogeny Inference Package) version 3.5. Department of Genetics, University of Washington, Seattle, WA, USA.

Fitch, W. C. \& Margoliash, E. (1967). Construction of phylogenetic trees. Science 155, 279-284.

Fox, G. E., Wisotzkey, J. D. \& Jurtshuk, P., Jr (1992). How close is close: 16S rRNA sequence identity may not be sufficient to guarantee species identity. Int J Syst Bacteriol 42, 166-170.

Gardner, M. W. \& Kendrick, J. B. (1921). Bacterial spot of tomato. J Agr Res 21, 123-156.

Gardner, M. W. \& Kendrick, J. B. (1923). Bacterial spot of tomato and pepper. Phytopathology 13, 307-315.

Hauben, L., Vauterin, L., Swings, J. \& Moore, R. E. B. (1997). Comparison of $16 \mathrm{~S}$ ribosomal DNA sequences of all Xanthomonas species. Int J Syst Bacteriol 47, 328-335.

Hildebrand, D. C., Palleroni, N. J. \& Schroth, M. N. (1990). Deoxyribonucleic acid relatedness of 24 xanthomonad strains representing 23 Xanthomonas campestris pathovars and Xanthomonas fragariae. J Appl Bacteriol 68, 263-269.

Innes, M. A., Gelfand, D. H. \& Sninsky, J. J. (1995). $P C R$ Strategies. New York: Academic Press. 
Johnson, J. L. (1994). Similarity analysis of DNAs. In Methods for General and Molecular Bacteriology, pp. 655-682. Edited by P. Gerhardt, R. G. E. Murray \& N. R. Krieg. Washington, DC: American Society for Microbiology.

Jones, J. B., Stall, R. E., Somodi, G. C., Bouzar, H. \& Hodge, N. C. (1995). A third tomato race of Xanthomonas campestris pv. vesicatoria. Plant Dis 79, 395-398.

Kimura, M. (1980). A simple method for estimating evolutionary rate of base substitutions through comparative studies of nucleotide sequences. J Mol Evol 16, 111-120.

Kumar, S., Tamura, K. \& Nei, M. (1994). MEGA: molecular evolutionary genetic analysis software for microcomputers. CABIOS 10, 189-191.

Leblond-Bourget, N., Philippe, H., Mangin, I. \& Decaris, B. (1996). $16 \mathrm{~S}$ rRNA and $16 \mathrm{~S}$ to $23 \mathrm{~S}$ internal transcribed apacer sequence analyses reveal inter- and intraspecific Bifidobacterium phylogeny. Int J Syst Bacteriol 46, 102-111.

Leite, R. P., Egel, D. S. \& Stall, R. E. (1994). Genetic analysis of $h r p$-related DNA sequences of Xanthomonas campestris strains causing diseases of citrus. Appl Environ Microbiol 60, 1078-1086.

Nei, M. (1987). Molecular Evolutionary Genetics. New York: Columbia University Press.

Nei, M. \& Li, W.-H. (1979). Mathematical model for studying genetic variation in terms of restriction enconucleases. Proc Natl Acad Sci USA 76, 5269-5273.

Olsen, G. J., Woese, C. R. \& Overbeek, R. (1994). The winds of evolutionary change: breathing new life into microbiology. $J$ Bacteriol 176, 1-6.

Palleroni, N. J., Hildebrand, D. C., Schroth, M. N. \& Hendson, M.
(1993). Deoxyribonucleic acid relatedness of 21 strains of Xanthomonas species and pathovars. J Appl Bacteriol 75, 441-446.

Ponsonnet, C. \& Nesme, X. (1994). Identification of Agrobacterium strains by PCR-RFLP analysis of pTi and chromosomal regions. Arch Microbiol 161, 300-309.

Saitou, N. \& Nei, M. (1987). The neighbor-joining method: new method for reconstructing phylogenetic trees. Mol Biol Evol 4, 406-425.

Stall, R. E., Beaulieu, C., Egel, D. S., Hodge, N. C., Leite, R. P., Minsavage, G. V., Bouzar, H., Jones, J. B., Alvarez, A. M. \& Benedict, A. A. (1994). Two genetically diverse groups of strains are included in Xanthomonas campestris pv. vesicatoria. Int $J$ Syst Bacteriol 44, 47-53.

Šutic, D. (1957). Bakterioze crvenog patlidzana (Tomato bacteriosis). In Posebna Izd Inst Zasht Bilja Beograd, vol. 6, pp. 1-65 (special edition). Beograd: Institute of Plant Protein. (English summary: Rev Appl Mycol 36, 734-735.)

Swofford, D. L. (1993). PAUP: phylogeny analysis using parsimony, version 3.1.1. Champaign, IL: Natural History Survey.

Thompson, J. D., Higgins, D. G. \& Gibson, T. J. (1994). CLUSTAL W: improving the sensitivity of progressive multiple sequence alignment through sequence weighting, position specific gap penalties and weight matirx choice. Nucleic Acids Res 22, 4673-4680.

Vauterin, L., Swings, J., Vauterin, L. \& 13 other authors (1990). Towards an improved taxonomy of Xanthomonas. Int J Syst Bacteriol 40, 312-316.

Vauterin, L., Hoste, B., Kersters, K. \& Swings, J. (1995). Reclassification of Xanthomonas. Int J Syst Bacteriol 45, 472-489. 